medRxiv preprint doi: https://doi.org/10.1101/2020.03.18.20038463; this version posted March 20, 2020. The copyright holder for this preprint (which was not certified by peer review) is the author/funder, who has granted medRxiv a license to display the preprint in It is made available under a CC-BY-ND 4.0 International license .

\title{
Burnout in gastroenterology registrars: a pilot study of trainees in
}

\section{the East of England}

3 John Ong ${ }^{1,2,3}$, Carla Swift ${ }^{4}$, Wanyen $\mathrm{Lim}^{5}$, Sharon Ong ${ }^{5}$, Yasseen Al-Naeeb ${ }^{4}$, Arun

4 Shankar $^{6}$

5

$6{ }^{1}$ Department of Engineering, University of Cambridge, Cambridge, UK

$7 \quad{ }^{2}$ Department of Medicine, National University of Singapore, Singapore

$8 \quad{ }^{3}$ East of England Gastroenterology Training Programme, Cambridge, UK

$9{ }^{4}$ Department of Gastroenterology, Bedford Hospital NHS Trust, Bedford, UK

$10{ }^{5}$ Department of Anaesthesia, Singapore General Hospital, Singapore

$11{ }^{6}$ Department of Gastroenterology, Norfolk \& Norwich University Hospital NHS Trust,

12 Norwich, UK

14 Corresponding author: Dr John Ong, Department of Engineering, University of 15 Cambridge, Trumpington Street, CB2 1PZ, UK. Tel: +44-1223-332600, Email: $16 \quad$ jo401@cam.ac.uk 


\section{ABSTRACT (250/250 words)}

22 Objective: The scale of burnout in UK gastroenterology trainees and the feasibility to determine its prevalence using the validated Maslach Burnout Inventory Human

24 Services Survey (MBI-HSS) tool are unknown. A region-wide pilot study was conducted to determine the uptake of a 31-item questionnaire and estimate the prevalence of burnout in gastroenterology trainees within the East of England deanery (EoE). Symptom severity across the three domains of burnout (emotional exhaustion, depersonalisation, and low personal accomplishment), and frequently experienced stressors by gastroenterology trainees were also studied.

Design: This was a cross-sectional study involving gastroenterology trainees from 16 hospitals across EoE using a 31-item questionnaire. The questionnaire consisted of the 22-item MBI-HSS and 9 additional free-text questions. All gastroenterology trainees in EoE were invited to complete the anonymized survey online. Data were analysed quantitatively and qualitatively.

Results: Uptake of the survey was above-average; $44.0 \%$ (40/91) response rate. $57.5 \%$ (23/40) of gastroenterology trainees suffered emotional exhaustion. $23.5 \%$ (8/34) had depersonalisation and 63.9\% (23/36) experienced low professional accomplishment. Burnout prevalence was $35.3 \%$ (12/34). Only $48.4 \%(15 / 31)$ of gastroenterology trainees were aware of professional support services within EoE. Stressors related to service requirements and professional relationships were commonly reported; $65.6 \%$ and $25.0 \%$ respectively.

42 Conclusions: It is feasible to use a 31-item questionnaire to detect and study burnout in a national cohort of gastroenterology trainees. Burnout in EoE gastroenterology trainees was high and this may reflect the national prevalence within the specialty. Larger 
medRxiv preprint doi: https://doi.org/10.1101/2020.03.18.20038463; this version posted March 20,2020. The copyright holder for this preprint (which was not certified by peer review) is the author/funder, who has granted medRxiv a license to display the preprint in It is made available under a CC-BY-ND 4.0 International license .

45 studies, greater awareness of burnout, and better access to professional support services

46 are needed.

47

48

49

50

51

52

53

54

55

56

57

58

59

60

61

62

63 


\section{What is already known about the subject?}

- Burnout in physicians is a growing problem worldwide which can lead to personal ill-health and suboptimal patient care.

- Burnout in young gastroenterology fellows in the US are reported as high as $50 \%$ but the prevalence in UK gastroenterology trainees is unknown.

- The Maslach Burnout Inventory - Human Services Survey (MBI-HSS) is the most validated tool to determine physician burnout but survey length may affect uptake by UK gastroenterology trainees and the feasibility of future studies.

\section{What are the new findings?}

- This pilot study demonstrated the feasibility of a 31-item questionnaire which included the MBI-HSS in studying burnout in UK gastroenterology trainees.

- Emotional exhaustion and a sense of low personal accomplishment affect more than half of gastroenterology trainees within the East of England.

- The prevalence of burnout in UK gastroenterology trainees is estimated to be high (35.3\%) but larger studies are needed.

- Approximately half of gastroenterology trainees in the East of England were not aware of existing support services to help them cope with burnout.

\section{How might it impact on clinical practice in the foreseeable future?}

- This pilot study may increase the awareness of burnout among UK trainees and trainers in gastroenterology.

- An estimate of burnout prevalence in UK gastroenterology trainees is provided so future research and remediation measures in the specialty can be justified. 
Burnout is an increasingly recognised occupational hazard among clinicians worldwide.

It recently has been recognized as an "occupational phenomenon" in the 11 th revision of the International Classification of Disease (ICD-11), and globally 30-50\% of clinicians are estimated to have symptoms of burnout.[1] It is typically characterized by symptoms across three domains: emotional exhaustion, depersonalization and a sense of low personal accomplishment (self-worth); the latter two domains have recently been referred to as "cynicism" and "reduced professional efficacy" respectively.[2] These symptoms exist on a scale of varying severity and the lack of awareness of its nature can lead to its under-recognition.[3] Unaddressed, clinician burnout can have a negative impact on patient outcomes through impaired professionalism, poor communication, decreased patient satisfaction, professional errors, near misses and even patient harm.[1] To clinicians, burnout may also cause depression and suicidal ideations, sleep disturbances, alcoholism, musculoskeletal disorders, hypertension and ischaemic heart disease.[4-7] Nonetheless, burnout is reversible and well placed support mechanisms are vital in the timely intervention and preservation of mental well being of clinicians in distress, especially those in the early stages of their careers. volumes, especially in the public sector. Unsurprisingly, the prevalence of burnout in gastroenterology fellows and young gastroenterologists have been reported as high as $54 \%$ in the US.[3,8] In the UK, gastroenterology training is equally demanding; trainees often hold many responsibilities involving general medical on calls, patient care in 30-40 bedded speciality wards, inpatient consults, outpatient clinics, endoscopy lists, speciality licensing exams, and for some, research commitments. Importantly, the 
medRxiv preprint doi: https://doi.org/10.1101/2020.03.18.20038463; this version posted March 20, 2020. The copyright holder for this preprint (which was not certified by peer review) is the author/funder, who has granted medRxiv a license to display the preprint in It is made available under a CC-BY-ND 4.0 International license .

111 prevalence of burnout in UK gastroenterology trainees has not been previously

112 determined and the scale of the problem remains unknown.

113 Several tools have been developed to detect burnout. These include, but are not limited 114 to the 22-item Maslach Burnout Inventory Human Services Survey (MBI-HSS), the 19115 item Copenhagen Burnout Inventory, and the 16-item Oldenburg Burnout Inventory. 116 The MBI-HSS is by far the most extensively validated and widely used tool in medical 117 professionals.[9,10] However, when the 22-item MBI-HSS is supplemented with 118 additional questions (e.g. demographic data collection) as is often the case, resulting 119 questionnaires are usually extensive and yield low response rates.[11] We designed a 31-item questionnaire which contained both the 22-item MBI-HSS and 9 free-text questions. It was unknown if the response rate from UK gastroenterology trainees to 122 this long questionnaire would be adequate for meaningful data analysis; typical response rates for US-based studies of gastroenterology fellows and gastroenterologists range from $8.1 \%$ to $12 \% .[8,12,13]$ Furthermore, a recent 64 -item survey on stress in UK gastroenterologists yielded a response rate of only $29 \%$.[14]

We hypothesized that burnout could be accurately detected using the MBI-HSS and survey response rates could be optimised by using streamlined questions. The objectives of this pilot study were to: (i) evaluate the uptake of a burnout questionnaire by response rates in a local trainee cohort before extending this study nationally, (ii) obtain an estimate of burnout prevalence within the East of England deanery (EoE), and (iii) understand common stressors that UK gastroenterology trainees face. A response rate of $>30 \%$ was defined as acceptable since this is higher than typical response rates reported in un-incentivised studies of burnout.[15] 
medRxiv preprint doi: https://doi.org/10.1101/2020.03.18.20038463; this version posted March 20, 2020. The copyright holder for this preprint (which was not certified by peer review) is the author/funder, who has granted medRxiv a license to display the preprint in It is made available under a CC-BY-ND 4.0 International license.

134 For the benefit of readers not familiar with the UK gastroenterology training system, 135 we use the terms "gastroenterology registrars" and "gastroenterology trainees" 136 interchangeably for better clarity. Standard specialty training in gastroenterology within 137 the UK spans 5 years of fulltime clinical training (ST3, ST4, ST5, ST6 and ST7).

METHODS

\section{Design and administration of the questionnaire}

A two-part questionnaire was designed to detect the presence of burnout and collect qualitative data for further analysis. The first part comprised of the 22-question MBIHSS which assessed burnout symptoms in the three domains of emotional exhaustion, depersonalisation (or cynicism) and a sense of low personal achievements (or professional efficacy). The second part comprised of 9 free-text questions.

For the 22 questions that related to the MBI-HSS, each question was graded on a sevenpoint Likert scale according to the frequency of symptoms, ranging from "never" (0) to "every day" (6). The Cronbach alpha in each domain was greater than 0.7. Scores from questions within each domain were summated and the average score was calculated for each respondent. Respondent scores were assessed for abnormal values which were provided in the proprietary MBI Manual 4th Edition (Method 2).[16] Abnormal values (proprietary) were derived from a population of 6,269 healthcare workers using the following formulae: Abnormal $\mathrm{EE}=$ Mean $+\left(\mathrm{SD}^{*} 0.5\right)$, Abnormal $\mathrm{DP}=$ Mean + $(\mathrm{SD} * 1.25)$, and Abnormal LPA $=$ Mean $+\left(\mathrm{SD}^{*} 0.1\right) \cdot[16]$ The higher the summated score or average score in the emotional exhaustion (EE) and depersonalisation (DP) subscales, the more frequent and severe the symptoms. Conversely, in the subscale measuring low 
personal accomplishment (LPA), the lower the summated score or average score, the more severe the symptoms. Individual summated scores were used to determine burnout (Method 1).[16] Clinical burnout was defined using the Maslach recommended criteria as the presence of either a high summated EE score with a high summated DP score, or a high summated EE score with a low summated LPA score (summated EE $\geq 27$ and summated $\mathrm{DP} \geq 13$, or summated $\mathrm{EE} \geq 27$ and summated $\mathrm{LPA} \leq 31$ ).[17]

The 9 free-text questions (Supplementary Table 1) in the second part of the questionnaire gathered demographic data as well as information on the most significant stressors that trainees perceived. One question on General Internal Medical (GIM) on calls was included because it is widely accepted that the acute medical registrar role is a highly demanding and stressful responsibility within the UK [18], and therefore may have had an effect on burnout rates.

A license to reproduce the MBI-HSS was obtained (www.mindgarden.com) and the MBI-HSS questions, together with the supplementary questions, were transcribed to an online platform (www.surveymonkey.co.uk). For the ease of processing raw data, the entire questionnaire was divided into four pages; page 1 contained 9 questions on EE, page 2 contained 8 questions on LPA, page 3 contained 5 questions on DP, and page 4 contained the 9 free-text questions. An electronic link to the questionnaire was then circulated to all 91 gastroenterology trainees within EoE via work and personal email, and data was collected between 15 January 2020 and 15 February 2020. A reminder email was sent on 29 Jan 2020. All responses were anonymised. Phone reminders were not utilised to preserve respondent anonymity.

Data from the MBI-HSS and parts of supplementary questions were analysed quantitatively. The remaining questions in the second part of the questionnaire were 
analysed qualitatively. Trainees were asked for the most significant job-related factor that contributed to their stress levels, and their responses were grouped under the most appropriate of the four themes: service requirements (workload, staffing levels etc), professional relationships (with colleagues and patients), training (e.g. exams, length of training, program requirements) and others.

\section{Statistical analyses}

MedCalc 19.1.5 was used to perform the statistical analyses. Trainee variables were results were reported as mean \pm standard deviation and non-parametric results were reported as median and inter-quartile range (IQR). Age of trainees between burnt out and non-burnt out groups were compared using the Mann-Whitney U test. When numbers were greater than five in a contingency table, the chi-squared test was used to test for differences in burnout proportions between groups; training grades and training centres (tertiary centre, district general hospital and research centre). When trainee numbers were small $(\mathrm{n} \leq 5)$ in a contingency table, Fisher's exact test was used to calculate p-values for better accuracy; employment status (full-time vs. less than fulltime), gender (male vs. female), and GIM on calls (yes vs. no).

Two-tailed $p$ values were reported for all tests and the significance level was set at $95 \%$.

Bonferroni correction was applied for multiple hypothesis testing if a significant $p$-value was obtained. Regression models were not used because the small sample size would not provide accurate results for meaningful interpretation.[20] A logistic regression model to identify relationships between trainee associated variables and burnout will be used in a planned national study where sample size would be considerably larger. 

required (Appendix 1). All participants were automatically anonymised by the online survey platform and trainees were made aware of this in their invitation email. Trainees were also informed the survey was for research purposes and participation was voluntary. Completion of the survey conferred implied consent and the authors only received anonymised responses with no trainee identifiable information. There were no risks posed to participants and participation in the survey was not incentivised.

\section{Patient and Public Involvement}

This study did not involve any members of the public or patients.

\section{Exclusion Criteria And Missing Data}

217 Missing data from incomplete DP and LPA questions were not used in the calculation 218 of burnout rates. Average DP and LPA scores were calculated from incomplete DP and 219 LPA questions, as permissible and advised by product literature. Missing data from the second part of the survey were not included in the respective fields of analysis. All authors in this paper were excluded from this study.

\section{RESULTS}

\section{Response rates}

224 The uptake of the questionnaire was good, achieving a response rate of $44.0 \%$ (41/90). $62.5 \%(25 / 40)$ of all responses were received within the first 2 weeks of the survey, $35 \%(14 / 40)$ of responses were received within 1 week of the reminder email being sent and $2.5 \%(1 / 40)$ responded in the last week of the survey. There was a $100 \%(40 / 40)$ 
medRxiv preprint doi: https://doi.org/10.1101/2020.03.18.20038463; this version posted March 20, 2020. The copyright holder for this preprint (which was not certified by peer review) is the author/funder, who has granted medRxiv a license to display the preprint in It is made available under a CC-BY-ND 4.0 International license.

228

229

231

completion rate for questions on $\mathrm{EE}, 90.0 \%$ (36/40) completion rate for questions on LPA, and 85.0\% (34/40) completion rate for questions on DP. For the second part of the questionnaire, 65.0\% (26/40) of respondents completed all 9 questions.

\section{Demographics of respondents}

Most gastroenterology trainees that responded to the survey were aged between 30-35 years old with the mode of respondents being ST6 (i.e. the fourth year out of five years of standard gastroenterology training). There were more male than female respondents however this is reflective of the number of female gastroenterologists including gastroenterology trainees within the UK (21-39\%)[21]. There were slightly more gastroenterology trainees who were working in district general hospitals (DGHs) than tertiary centres: $43.8 \%$ vs. $53.1 \%$. Most of the gastroenterology trainees were involved in GIM on calls. A summary of the demographic data is displayed in Table 1.

Table 1: Demographic data of EoE gastroenterology trainees who responded in the survey.

\begin{tabular}{|l|c|l|}
\hline \multicolumn{1}{|c|}{ Trainee Demographics } & Results & \multicolumn{1}{c|}{ Footnotes } \\
\hline 1. Age (median); IQR & 32 yrs; IQR 30-35yrs & Mean $=33.1$ yrs \\
\hline 2. Training grade (mode) & ST6 & $\begin{array}{l}\text { ST3=16.7\%, ST4 }=23.3 \%, \text { ST5 }=16.7 \%, \\
\text { ST6=30.0\%, ST7 }=13.3 \%\end{array}$ \\
\hline 3. Full-time training & $87.9 \%$ & LTFT trainees $=12.1 \%$ \\
\hline 4. Gender & $\begin{array}{c}\text { Male }=71.0 \%, \\
\text { Female }=29.0 \%\end{array}$ & \\
\hline 5. Training centres & $\begin{array}{c}\text { Tertiary }=43.8 \%, \\
\text { DGH }=53.1 \%\end{array}$ & Research centre $=3.1 \%$ \\
\hline 6. GIM oncalls & \multicolumn{2}{|c|}{$\begin{array}{l}\text { Yes }=87.5 \%, \\
\text { No }=12.5 \%\end{array}$} \\
\hline
\end{tabular}

Internal Medicine. 
medRxiv preprint doi: $h t t p s: / / d o i . o r g / 10.1101 / 2020.03 .18 .20038463$; this version posted March 20, 2020. The copyright holder for this preprint (which was not certified by peer review) is the author/funder, who has granted medRxiv a license to display the preprint in

It is made available under a CC-BY-ND 4.0 International license .

The estimated prevalence of burnout and burnout related symptoms were high in

gastroenterology trainees.

Symptoms of burnout were high in gastroenterology trainees (Figure 1). Emotional

exhaustion was present in $57.5 \%(23 / 40)$ of all respondents (EE mean 3.9. \pm 0.8$)$. Of

these, $43.5 \%(10 / 23)$ experienced symptoms once a week or more frequently.

Depersonalisation was detected in $23.5 \%(8 / 34)$ of all trainees (DP mean $3.9 \pm 0.6$ ), of these, $62.5 \%(5 / 8)$ experienced symptoms once a week or more frequently. $63.9 \%$ (23/36) of all respondents experienced a sense of low personal accomplishment (LPA mean $3.8 \pm 0.7)$, of these, $52.2 \%(12 / 23)$ felt some sort of job satisfaction or fulfilment once a week or less. Overall, burnout was present in 35.3\% (12/34) of gastroenterology trainees. Despite the high prevalence of burnout symptoms, only $48.4 \%$ (15/31) of gastroenterology trainees were aware that there were professional support services within the deanery to help trainees in distress.

\section{Characteristics of burnt-out gastroenterology trainees}

A summary of the characteristics between burnt out and non-burnt out gastroenterology trainees is displayed in Table 2. Briefly, burnt out gastroenterology trainees were observed to be slightly older, in later stages of training (ST5 and ST6 training grades), in full-time employment, working in tertiary centres, and did GIM on calls, however, none of these differences had any statistical significance when tested. For research purposes, the summated sub-scale scores were calculated and the results for the burntout group were as follow: $\mathrm{EE}=34.0$ (median: 32 , IQR 29-40), $\mathrm{DP}=16.3 \pm 7.4$, and $\mathrm{LPA}=28.2 \pm 7.2$. For the non-burnt group, the average of summated sub-scale scores were $\mathrm{EE}=21.2 \pm 10.8, \mathrm{DP}=7.6$ (median: 6, IQR 5-10), and LPA = $38.0 \pm 5.4$.

Table 2: Characteristics of burnt out and non-burnt out gastroenterology trainees. 
medRxiv preprint doi: https://doi.org/10.1101/2020.03.18.20038463; this version posted March 20, 2020. The copyright holder for this preprint (which was not certified by peer review) is the author/funder, who has granted medRxiv a license to display the preprint in perpetuity.

\begin{tabular}{|c|c|c|c|}
\hline Trainee variable & $\begin{array}{l}\text { Burnt out } \\
\text { (a) }\end{array}$ & $\begin{array}{c}\text { Non-burnt out } \\
\text { (b) }\end{array}$ & (a) vs. (b) \\
\hline Age (mean) & $34.1 \mathrm{yrs}$ & 32.6yrs & $p=0.11$ \\
\hline $\begin{array}{c}\text { Grade } \\
\text { ST3 } \\
\text { ST4 } \\
\text { ST5 } \\
\text { ST6 } \\
\text { ST7 }\end{array}$ & $\begin{array}{ll}20.0 \% & (1 / 5) \\
14.3 \% & (1 / 7) \\
80.0 \%(4 / 5) \\
55.6 \%(5 / 9) \\
25.0 \%(1 / 4)\end{array}$ & $\begin{array}{ll}80.0 \% & (4 / 5) \\
85.7 \% & (6 / 7) \\
20.0 \% & (1 / 5) \\
44.4 \% & (4 / 9) \\
75.0 \% & (3 / 4)\end{array}$ & $p=0.12$ \\
\hline $\begin{array}{l}\text { Employment status } \\
\text { Full-time } \\
\text { LTFT }\end{array}$ & $\begin{array}{c}41.4 \%(12 / 29) \\
0 \%(0)\end{array}$ & $\begin{array}{lr}58.6 \% & (17 / 29) \\
100 \% & (4 / 4)\end{array}$ & $p=0.27$ \\
\hline $\begin{array}{l}\text { Gender } \\
\text { Male } \\
\text { Female }\end{array}$ & $\begin{array}{lr}40.9 \% & (9 / 22) \\
33.3 \% & (3 / 9)\end{array}$ & $\begin{array}{l}59.1 \%(13 / 22) \\
66.7 \% \quad(6 / 9)\end{array}$ & $p=0.70$ \\
\hline $\begin{array}{l}\text { Training Centre } \\
\text { Tertiary } \\
\text { DGH } \\
\text { Research centre }\end{array}$ & $\begin{array}{l}42.9 \%(6 / 14) \\
29.4 \% \quad(5 / 17) \\
100 \% \quad(1 / 1)\end{array}$ & $\begin{array}{cc}57.1 \% & (8 / 14) \\
70.6 \% & (12 / 17) \\
0 \% & (0 / 0)\end{array}$ & $p=0.27$ \\
\hline $\begin{array}{l}\text { GIM on calls } \\
\text { Yes } \\
\text { No }\end{array}$ & $\begin{array}{rr}32.1 \% & (9 / 28) \\
50.0 \% & (2 / 4)\end{array}$ & $\begin{array}{lr}67.9 \% & (19 / 28) \\
50.0 \% & (2 / 4)\end{array}$ & $p=0.49$ \\
\hline
\end{tabular}

$27087.1 \%(27 / 31)$ of gastroenterology trainees stated that job-related factors contributed to

271 the most amount of stress in their lives, $12.9 \%$ (4/31) reported personal factors - family

272 relationships and personal finances. Figure 2 illustrates the frequency of job-related

273 stressors reported by gastroenterology trainees according to the themes. $65.6 \%(21 / 32)$

274 of trainees reported stressors related to service requirements, these comprised of 275 workload (56.2\%) and inadequate staffing levels (9.4\%). Professional relationships

276 were the second most frequently reported theme at $25.0 \%(8 / 32)$; these consisted of 277 difficult and unsupportive colleagues (9.4\%), expectations by seniors (9.4\%), difficult 278 patients $(3.1 \%)$, and expectations of patients $(3.1 \%)$. Stressors relating to training 279 requirements were reported at a frequency of $12.5 \%(4 / 32)$ which comprised speciality 

stressors that were reported include long commuting times between home and work $(6.3 \%)$ and length of speciality training $(3.1 \%)$.

\section{DISCUSSION}

This study has used the 22-item MBI-HSS to detect burnout although abbreviated versions (aMBI) of the tool exist. These include the 2-item, 9-item MBI or 12-item aMBI which are favoured by some researchers because they are easier to administer and can yield better response rates. However, we have chosen not to use an abbreviated version of the MBI because these can be unreliable; we have previously demonstrated that the 12-question MBI had a poor positive predictive value of $33.3 \%(95 \%$ confidence interval:27.5-39.8\%) and could overestimate the prevalence of burnout.[22] The study period was also capped at 1 month because given our experience in burnout studies of similar sample size, most of the responses were usually obtained within the first two weeks of the survey.[22] This is clearly evidenced in our observations of the current study as shown in the results. For the planned nationwide study, the study period will be extended to 3 months since the cohort size would be exponentially larger.

Even though the MBI-HSS is a well established tool, many researchers have adopted different criteria as well as numerical cut-off values to define burnout. Such heterogeneity in burnout definitions, as well as burnout tools, has precluded the accurate estimation of burnout in systematic reviews and meta-analyses.[9,23] In this study, burnout was defined by the Maslach-recommended criteria of "high EE and high DP" or "high EE and low PA" since this is the only definition that has been shown to have a clinical correlation; researchers have established that the combination of high scores in these domains correlate closely to work-related neurasthenia as defined by ICD- 

be $35.3 \%$ but this is possibly an underestimation because burnt out trainees may not have engaged in this study.

Nonetheless, this study has demonstrated that the uptake of the 22-item MBI-HSS

higher than commonly reported response rates in burnout studies. Interestingly, although a $100 \%$ completion rate was achieved in the emotional exhaustion questions (page 1 of 4 on the online survey), the completion rate gradually declined as the questionnaire progressed: $90 \%$ for LPA questions (page 2), $85.0 \%$ for DP questions (page 3) and $65.0 \%$ for free-text questions (page 4). In a planned nationwide study, the authors will consolidate all questions onto 2 pages to improve the completion rate; the first page to contain the 22-item MBI-HSS and the second page to contain free-text questions.

In our results, burnt out trainees were observed to be slightly older (34.1yrs vs. 32.6yrs), in ST5 and ST6 training grades, in fulltime employment, working in tertiary centres, and did GIM on calls. However, these differences did not have any statistical significance when tested. The lack of statistical significance, however, does not imply the lack of association but rather could be a result of the small sample size. In the planned nationwide study, these factors could be analysed more meaningfully in a larger sample size with regression methods to test for associations. Also, it was unexpected that difficult and unsupportive colleagues would be the second most frequently reported stressor $(9.4 \%)$, jointly ranked with expectations by seniors $(9.4 \%)$ and poor staffing levels $(9.4 \%)$. The two former stressors may be addressed by interventions such as mentoring and mindfulness-based exercises [25-28], however the latter may prove to be more difficult for reasons discussed below. 
Within the UK, the demand for gastroenterology services is gradually increasing but almost half of advertised gastroenterology consultant posts remain unfilled.[21] Several years are needed to train or recruit manpower to fill these vacancies and it is therefore unsurprising that current gastroenterology consultants and trainees face heavy workloads, and as a result, may experience high levels of stress and burnout. Recently, a survey on stress among UK gastroenterologists found that $48 \%$ considered leaving their current hospital of work, $44 \%$ had lost their temper at work and $6 \%$ had contemplated suicide.[14] These strongly suggest further studies in burnout are needed, especially in gastroenterology trainees and young consultants since early stage burnout can diminish the size of the future workforce, negatively impacting its sustainability, and have detrimental effects on the health of both patients and clinicians. More importantly, we have found that only $48.4 \%$ of all gastroenterology trainees were aware of existing professional support services within EoE deanery to help trainees in distress. As a result, bespoke lectures on well being and wider advertisement of support services have been planned for gastroenterology trainees within EoE since the completion of the study.

Nonetheless, the scale of burnout within gastroenterology in the UK remains unknown and must first be understood before any meaningful interventions can be designed. Once a nationwide study of gastroenterology trainees has been completed, the authors intend to conduct similar studies involving gastroenterology consultants, nurses and allied health professionals that constitute the rest of the UK gastroenterology workforce. In so doing, burnout prevalence amongst the workforce, awareness of, and access to support services across the country could also be studied. been affected by response bias and non-response bias although these are inherent 

representative of the gastroenterology trainees throughout the UK therefore a larger HSS is the most reliable and validated tool to detect burnout to date, its limitation should be recognised because burnout syndrome itself is poorly characterized. Lastly, working hours and rota patterns in gastroenterology and GIM were not studied and therefore limited insight can be gained into the working environment of gastroenterology trainees. The authors acknowledge this was a compromise to achieve better response rates. Even though associations between longer working hours and burnout are known, the relationship is non-linear, often complex, and is influenced by many other factors such as personality traits (resilience) which are difficult to measure.

\section{Conclusion}

It is feasible to use a 31-item questionnaire comprising the MBI-HSS to determine the prevalence of burnout in gastroenterology trainees in a larger cohort study. Most gastroenterology trainees within EoE have symptoms of burnout and the prevalence of burnout was estimated at $35.3 \%$, however, larger scale studies are needed. Service requirements and professional relationships contribute the most stress to gastroenterology trainees in EoE. Greater awareness of burnout and better access to professional support services are needed.

Acknowledgements: This research was not funded however communications and access to literature were provided by the University of Cambridge. JO is funded by the 
medRxiv preprint doi: https://doi.org/10.1101/2020.03.18.20038463; this version posted March 20, 2020. The copyright holder for this preprint (which was not certified by peer review) is the author/funder, who has granted medRxiv a license to display the preprint in It is made available under a CC-BY-ND 4.0 International license.

377 W.D. Armstrong Doctoral Research Training Fellowship and a talent development grant 378 from the National University of Singapore.

379

380 Funding: None - this research received no specific grant from any funding agency in 381 the public, commercial or not-for-profit sectors.

383 Competing interests: None to declare

Author's contributions: Conceptualisation: JO, design: JO and CS, data curation JO and CS, statistical analysis: JO, manuscript preparation: JO, CS, LWY, revisions: SO, YAN, critical edits and supervision: AS.

Data sharing: No additional data is available

\section{REFERENCES}

1. West CP, Dyrbye LN, Erwin PJ, et al. Interventions to prevent and reduce physician burnout: a systematic review and meta-analysis. Lancet 2016;388:2272-81 implications for psychiatry. World Psychiatry 2016;15(2):103-11. 
medRxiv preprint doi: https://doi.org/10.1101/2020.03.18.20038463; this version posted March 20, 2020. The copyright holder for this preprint (which was not certified by peer review) is the author/funder, who has granted medRxiv a license to display the preprint in It is made available under a CC-BY-ND 4.0 International license.

3. Barnes EL, Ketwaroo GA, Shields HM. Scope of Burnout Among Young

397 Gastroenterologists and Practical Solutions from Gastroenterology and Other

398 Disciplines. Dig Dis Sci 2019;64,302-306.

399

4. Madsen IEH, Lange T, Borritz M, et al. Burnout as a risk factor for antidepressant

400 treatment - a repeated measures time-to-event analysis of 2936 Danish human service

401 workers. J Psychiatr Res 2015;65:47-52.

402

5. Peterson U, Demerouti E, Bergstrom G, et al. Burnout and physical and mental 403 health among Swedish healthcare workers. J Adv Nurs 2008;62:84-95.

404

6. Shanafelt TD, Sloan JA, Habermann TM. The well-being of physicians. Am J Med

405 2003; 114:513-519.

406

7. Sorour AS, El-Maksoud MMA. Relationship between musculoskeletal disorders,

407 job demands, and burnout among emergency nurses. Adv Emerg Nurs J 2012;34:272-

408 282.

409

8. DeCross AJ. The Current State of Professional Burnout in Gastroenterology. AGA

410

Perspect 2017;13:22-23

411

9. Rotenstein LS, Torre M, Ramos MA, et al. Prevalence of Burnout Among Physicians.

412 JAMA 2018;320:1131-1150.

413

10. Shi Y, Gugiu PC, Crowe RP, et al. A Rasch Analysis Validation of the Maslach

414 Burnout Inventory-Student Survey with Preclinical Medical Students. Teach Learn Med

415 2019;31:154-169. 
medRxiv preprint doi: $h t t p s: / / d o i . o r g / 10.1101 / 2020.03 .18 .20038463$; this version posted March 20, 2020. The copyright holder for this preprint (which was not certified by peer review) is the author/funder, who has granted medRxiv a license to display the preprint in It is made available under a CC-BY-ND 4.0 International license.

416 11. West CP, Dyrbye LN, Satele DV, et al. Concurrent Validity of Single-Item

417 Measures of Emotional Exhaustion and Depersonalization in Burnout Assessment. $J$

418 Gen Intern Med 2012;27,1445-1452.

419 12. Keswani RN, Taft TH, Coté GA, et al. Increased levels of stress and burnout are

420 related to decreased physician experience and to interventional gastroenterology career

421 choice: findings from a US survey of endoscopists. Am $J$ Gastroenterol.

$422 \quad 2011 ; 106: 1734-1740$.

423 13. Burke C, Surawicz CM, Oxentenko AS, et al. A national survey of burnout in 424 gastroenterologists. Am J Gastroenterol. 2017;112:S593.

14. Gleeson D, O'Shea C, Ellison $\mathrm{H}$, et al. Stress and its causes in UK gastroenterologists: results of a national survey by the British Society of

427 Gastroenterology. Frontline Gastroenterol 2019;10(1),43-49.

428 15. Roberts DL, Shanafelt TD, Dyrbye LN, et al. A national comparison of burnout and work-life balance among internal medicine hospitalists and outpatient general internists. J HospMed. 2014;9(3):176-81.

16. Maslach C, Jackson S, Leiter M. Maslach burnout inventory 4th Edition. Menlo Park, CA: Mind Garden 2018:10-74

433 17. Dyrbye LN, West CP, Shanafelt TD. Defining Burnout as a Dichotomous Variable. J Gen Intern Med 2009; 24:440.

18. Blayney S, Crowe A, Bray D. Survival as medical registrar on call: remember the doughnut. Clin Med (Lond) 2014;14,506-509. samples). Biometrika 1965;52(3-4):591-611. DOI:10.1093/biomet/52.3-4.591. 
medRxiv preprint doi: https://doi.org/10.1101/2020.03.18.20038463; this version posted March 20, 2020. The copyright holder for this preprint (which was not certified by peer review) is the author/funder, who has granted medRxiv a license to display the preprint in It is made available under a CC-BY-ND 4.0 International license.

20. Hart RA, Clark DH. Does size matter? Exploring the small sample properties of maximum likelihood estimation. Annual Meeting of the Midwest Political Science Association Chicago, IL: Midwest Political Science Association 1999:1-32.

21. The British Society of Gastroenterology. British Society of Gastroenterology Workforce Report. 2019. Available at: https://www.bsg.org.uk/workforcereports/workforce-report-2019/. [last accessed 14 Feb 2020].

22. Lim WY, Ong J, Ong S, et al. The Abbreviated Maslach Burnout Inventory Can Overestimate Burnout: A Study of Anesthesiology Residents. J Clin Med 2020;9,61:114. DOI:10.3390/jcm9010061

23. Sanfilippo F, Noto A, Foresta G, et al. Incidence and Factors Associated with Burnout in Anesthesiology: A Systematic Review. Biomed Res Int 2017; Article ID: 8648925 DOI: $10.1155 / 2017 / 8648925$

24. Schaufeli WB, Bakker A, Schaap C, et al. On the clinical validity of the Maslach Burnout Inventory and the Burnout Measure. Psychol Health 2001;16:565-82.

25. Keswani RN, Keefer L, Surawicz CM. Burnout in Gastroenterologists and How to Prevent it. Gastroenterology 2014;147,11-14.

26. Herring M, Forbes Kaufman R, Bogue R. Mentoring to help prevent physician burnout. Health Prog. 2016;97:74-77.

27. Harrison R, Hunter AJ, Sharpe B, et al. Survey of US academic hospitalist leaders about mentorship and academic activities in hospitalist groups. $J$ Hosp Med. 2011;6:5-. 28. Ong J, Swift C, Magill N, et al. The association between mentoring and training outcomes in junior doctors in medicine: an observational study. BMJ Open 2018;8:e20721. 
medRxiv preprint doi: https://doi.org/10.1101/2020.03.18.20038463; this version posted March 20, 2020. The copyright holder for this preprint (which was not certified by peer review) is the author/funder, who has granted medRxiv a license to display the preprint in It is made available under a CC-BY-ND 4.0 International license.

\section{$\%$ of respondents}

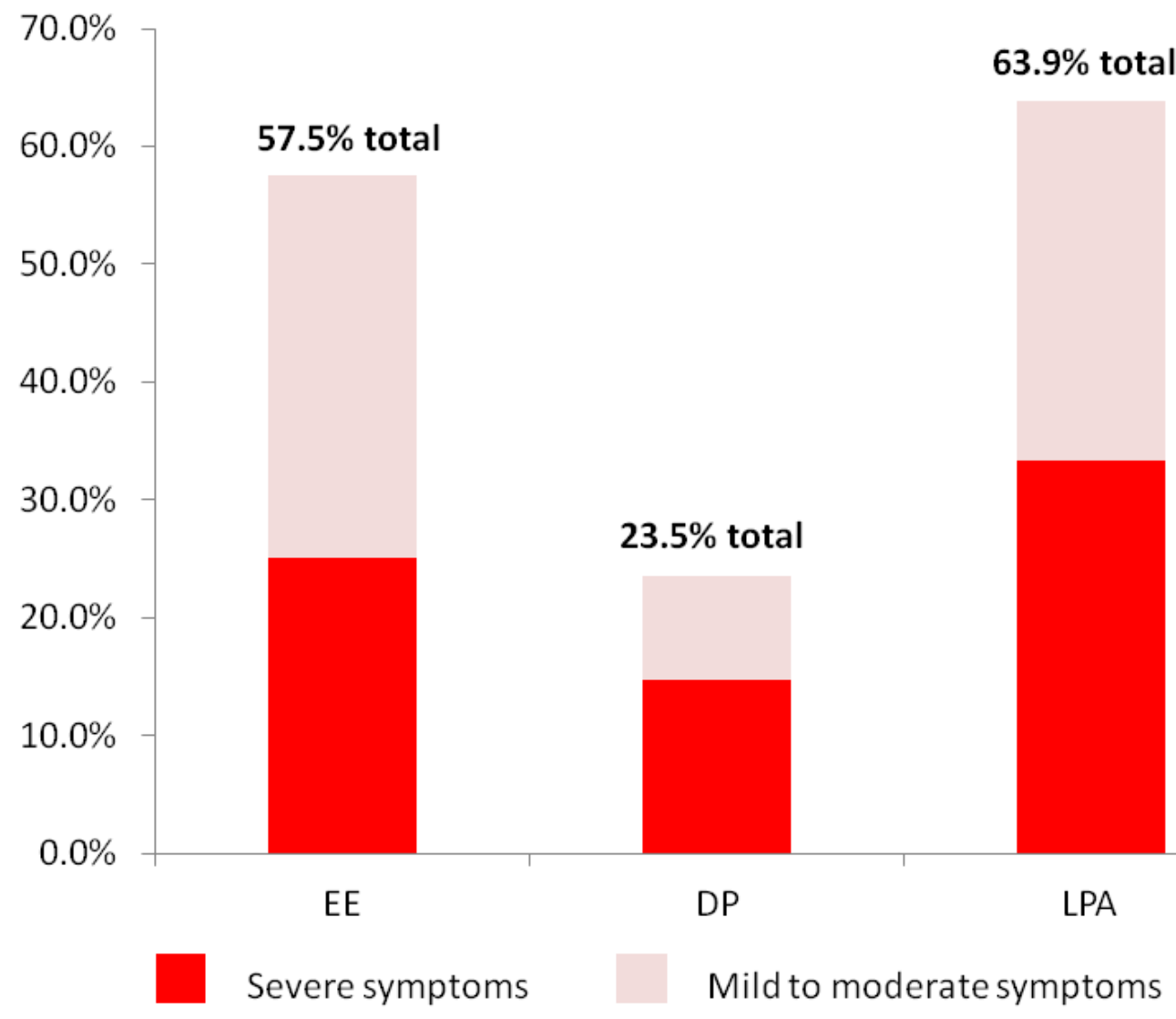

Figure 1 - Frequency of burnout symptoms among gastroenterology trainees in the EoE 
medRxiv preprint doi: https://doi.org/10.1101/2020.03.18.20038463; this version posted March 20, 2020. The copyright holder for this preprint (which was not certified by peer review) is the author/funder, who has granted medRxiv a license to display the preprint in

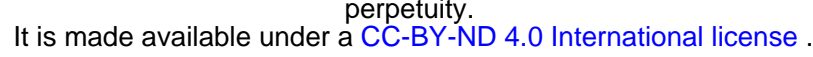

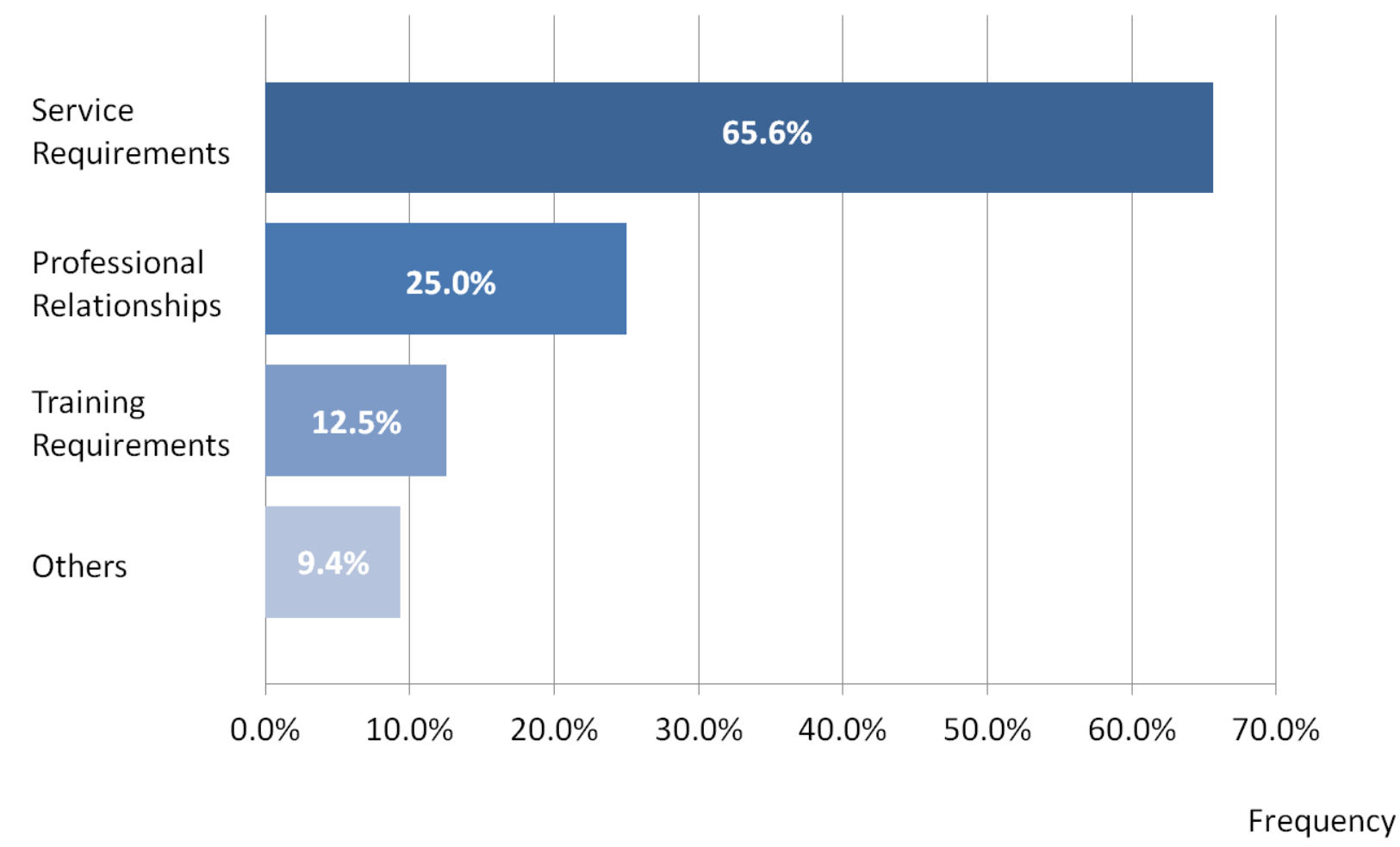

Figure 2: The frequency of significant stressors in gastroenterology trainees grouped by common themes. 
medRxiv preprint doi: https://doi.org/10.1101/2020.03.18.20038463; this version posted March 20, 2020. The copyright holder for this preprint (which was not certified by peer review) is the author/funder, who has granted medRxiv a license to display the preprint in It is made available under a CC-BY-ND 4.0 International license.

\section{Supplementary Table 1: Burnout Questionnaire Part 2 - Free text questions}

\begin{tabular}{|c|c|c|}
\hline Plea & ll in the blanks & \\
\hline $\mathbf{S} / \mathbf{N}$ & Question & Response \\
\hline 1 & Age: & \\
\hline 2 & Gender: & \\
\hline 3 & $\begin{array}{l}\text { Grade (e.g. ST3, clinical research fellow } \\
\text { etc.): }\end{array}$ & \\
\hline 4 & $\begin{array}{l}\text { Are you in fulltime or less than full time } \\
\text { training?: }\end{array}$ & \\
\hline 5 & $\begin{array}{l}\text { Do you work in a district hospital, } \\
\text { tertiary centre or research centre?: }\end{array}$ & \\
\hline 6 & $\begin{array}{l}\text { Do you do General Internal Medicine } \\
\text { oncalls?: }\end{array}$ & \\
\hline 7 & $\begin{array}{l}\text { Which area of your life contributes most } \\
\text { to your stress levels (e.g. job, personal } \\
\text { life, finances etc)?: }\end{array}$ & \\
\hline 8 & $\begin{array}{l}\text { Which job-related factor contributes } \\
\text { most to your stress levels (e.g. exams, } \\
\text { workload etc)?: }\end{array}$ & \\
\hline 9 & $\begin{array}{l}\text { Are you aware of any professional } \\
\text { support services for trainees in the } \\
\text { deanery?: }\end{array}$ & \\
\hline
\end{tabular}


Go straight to content.

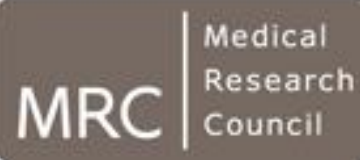

\section{Do I need NHS REC approval?}

\section{Authority}

To print your result with title and IRAS Project ID please enter your details below:

Title of your research:

Burnout in Gastroenterology Registrars

IRAS Project ID (if available):

$\mathrm{N} / \mathrm{A}$

Your answers to the following questions indicate that you do not need NHS REC approval for sites in England. However, you may need other approvals.

You have answered 'YES' to: Is your study research?

You answered 'NO' to all of these questions:

\section{Question Set 1}

- Is your study a clinical trial of an investigational medicinal product?

- Is your study one or more of the following: A non-CE marked medical device, or a device which has been modified or is being used outside of its CE mark intended purpose, and the study is conducted by or with the support of the manufacturer or another commercial company (including university spin-out company) to provide data for CE marking purposes?

- Does your study involve exposure to any ionising radiation?

- Does your study involve the processing of disclosable protected information on the Register of the Human Fertilisation and Embryology Authority by researchers, without consent?

\section{Question Set 2}

- Will your study involve potential research participants identified in the context of, or in connection with, their past or present use of services (adult and children's healthcare within the NHS and adult social care), including participants recruited through these services as healthy 
It is made available under a CC-BY-ND 4.0 International license controls?

- Will your research involve collection of tissue or information from any users of these services (adult and children's healthcare within the NHS and adult social care)? This may include users who have died within the last 100 years.

- Will your research involve the use of previously collected tissue or information from which the research team could identify individual past or present users of these services (adult and children's healthcare within the NHS and adult social care), either directly from that tissue or information, or from its combination with other tissue or information likely to come into their possession?

- Will your research involve potential research participants identified because of their status as relatives or carers of past or present users of these services (adult and children's healthcare within the NHS and adult social care)?

\section{Question Set 3}

- Will your research involve the storage of relevant material from the living or deceased on premises in the UK, but not Scotland, without an appropriate licence from the Human Tissue Authority (HTA)? This includes storage of imported material.

- Will your research involve storage or use of relevant material from the living, collected on or after 1st September 2006, and the research is not within the terms of consent from the donors, and the research does not come under another NHS REC approval?

- Will your research involve the analysis of DNA from bodily material, collected on or after 1st September 2006, and this analysis is not within the terms of consent for research from the donor? And/or: Will your research involve the analysis of DNA from materials that do not contain cells (for example: serum or processed bodily fluids such as plasma and semen) and this analysis is not within the terms of consent for research from the donor?

\section{Question Set 4}

- Will your research involve at any stage intrusive procedures with adults who lack capacity to consent for themselves, including participants retained in study following the loss of capacity?

- Is your research health-related and involving prisoners?

- Does your research involve xenotransplantation?

- Is your research a social care project funded by the Department of Health and Social Care (England)?

If your research extends beyond England find out if you need NHS REC approval by selecting the 'OTHER UK COUNTRIES' button below.

\section{OTHER UK COUNTRIES}




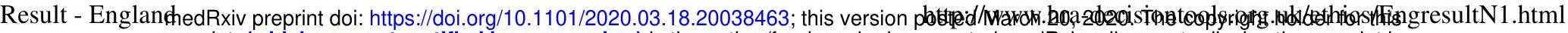
preprint (which was not certified by peer review) is the author/funder, who has granted medRxiv a license to display the preprint in

perpetuity.
It is made available under a CC-BY-ND 4.0 International license .

suggests that you do not require NHS REC approval follow this link for final confirmation and further information.

Print This Page

NOTE: If using Internet Explorer please use browser print function.

About this tool Feedback Contact Glossary 


\section{STROBE 2007 (v4) Statement-Checklist of items that should be included in reports of cross-sectional studies}

\begin{tabular}{|c|c|c|c|}
\hline Section/Topic & $\begin{array}{l}\text { Item } \\
\#\end{array}$ & Recommendation & Reported on page \# \\
\hline \multirow[t]{2}{*}{ Title and abstract } & \multirow[t]{2}{*}{1} & (a) Indicate the study's design with a commonly used term in the title or the abstract & 2 \\
\hline & & (b) Provide in the abstract an informative and balanced summary of what was done and what was found & 2,3 \\
\hline \multicolumn{4}{|l|}{ Introduction } \\
\hline Background/rationale & 2 & Explain the scientific background and rationale for the investigation being reported & 5,6 \\
\hline Objectives & 3 & State specific objectives, including any prespecified hypotheses & 6 \\
\hline \multicolumn{4}{|l|}{ Methods } \\
\hline Study design & 4 & Present key elements of study design early in the paper & 7 \\
\hline Setting & 5 & $\begin{array}{l}\text { Describe the setting, locations, and relevant dates, including periods of recruitment, exposure, follow-up, and data } \\
\text { collection }\end{array}$ & 8 \\
\hline Participants & 6 & (a) Give the eligibility criteria, and the sources and methods of selection of participants & 8 \\
\hline Variables & 7 & $\begin{array}{l}\text { Clearly define all outcomes, exposures, predictors, potential confounders, and effect modifiers. Give diagnostic criteria, if } \\
\text { applicable }\end{array}$ & 7,8 \\
\hline $\begin{array}{l}\text { Data sources/ } \\
\text { measurement }\end{array}$ & $8^{*}$ & $\begin{array}{l}\text { For each variable of interest, give sources of data and details of methods of assessment (measurement). Describe } \\
\text { comparability of assessment methods if there is more than one group }\end{array}$ & 8,9 \\
\hline Bias & 9 & Describe any efforts to address potential sources of bias & 8 \\
\hline Study size & 10 & Explain how the study size was arrived at & 8,9 \\
\hline Quantitative variables & 11 & $\begin{array}{l}\text { Explain how quantitative variables were handled in the analyses. If applicable, describe which groupings were chosen and } \\
\text { why }\end{array}$ & $8-10$ \\
\hline \multirow[t]{5}{*}{ Statistical methods } & 12 & (a) Describe all statistical methods, including those used to control for confounding & 8,9 \\
\hline & & (b) Describe any methods used to examine subgroups and interactions & 8,9 \\
\hline & & (c) Explain how missing data were addressed & 10 \\
\hline & & (d) If applicable, describe analytical methods taking account of sampling strategy & NA \\
\hline & & (e) Describe any sensitivity analyses & NA \\
\hline Results & & & \\
\hline
\end{tabular}




\begin{tabular}{|c|c|c|c|}
\hline Participants & $13^{*}$ & $\begin{array}{l}\text { (a) Report numbers of individuals at each stage of study-eg numbers potentially eligible, examined for eligibility, } \\
\text { confirmed eligible, included in the study, completing follow-up, and analysed }\end{array}$ & 8,10 \\
\hline & & (b) Give reasons for non-participation at each stage & NA \\
\hline & & (c) Consider use of a flow diagram & NA \\
\hline \multirow[t]{2}{*}{ Descriptive data } & $14^{*}$ & $\begin{array}{l}\text { (a) Give characteristics of study participants (eg demographic, clinical, social) and information on exposures and potential } \\
\text { confounders }\end{array}$ & 11,12, Table 1 \\
\hline & & (b) Indicate number of participants with missing data for each variable of interest & 10,11 \\
\hline Outcome data & $15^{*}$ & Report numbers of outcome events or summary measures & 10-14, Fig 1, Fig 2 \\
\hline \multirow[t]{3}{*}{ Main results } & 16 & $\begin{array}{l}\text { (a) Give unadjusted estimates and, if applicable, confounder-adjusted estimates and their precision (eg, } 95 \% \text { confidence } \\
\text { interval). Make clear which confounders were adjusted for and why they were included }\end{array}$ & $10-14$ \\
\hline & & (b) Report category boundaries when continuous variables were categorized & 11,12 \\
\hline & & (c) If relevant, consider translating estimates of relative risk into absolute risk for a meaningful time period & NA \\
\hline Other analyses & 17 & Report other analyses done-eg analyses of subgroups and interactions, and sensitivity analyses & 12,13, Table 2 \\
\hline \multicolumn{4}{|l|}{ Discussion } \\
\hline Key results & 18 & Summarise key results with reference to study objectives & $14,15,16$ \\
\hline Limitations & 19 & $\begin{array}{l}\text { Discuss limitations of the study, taking into account sources of potential bias or imprecision. Discuss both direction and } \\
\text { magnitude of any potential bias }\end{array}$ & 15,16 \\
\hline Interpretation & 20 & $\begin{array}{l}\text { Give a cautious overall interpretation of results considering objectives, limitations, multiplicity of analyses, results from } \\
\text { similar studies, and other relevant evidence }\end{array}$ & 15,16 \\
\hline Generalisability & 21 & Discuss the generalisability (external validity) of the study results & $14,15,16$ \\
\hline \multicolumn{4}{|l|}{ Other information } \\
\hline Funding & 22 & $\begin{array}{l}\text { Give the source of funding and the role of the funders for the present study and, if applicable, for the original study on } \\
\text { which the present article is based }\end{array}$ & 18 \\
\hline
\end{tabular}

*Give information separately for cases and controls in case-control studies and, if applicable, for exposed and unexposed groups in cohort and cross-sectional studies.

Note: An Explanation and Elaboration article discusses each checklist item and gives methodological background and published examples of transparent reporting. The STROBE checklist is best used in conjunction with this article (freely available on the Web sites of PLoS Medicine at http://www.plosmedicine.org/, Annals of Internal Medicine at http://www.annals.org/, and Epidemiology at http://www.epidem.com/). Information on the STROBE Initiative is available at www.strobe-statement.org. 